\title{
Soil and Plant Nutrient Status as Influenced by Phosphorus Biofertilizers in Sweet Corn (Zea mays L.)
}

\section{Prasanth $B^{1 *}$, Hemalatha $S^{2}$, Prabhakara Reddy $G^{3}$ and Nagamadhuri $\mathrm{K} \mathrm{V}^{4}$}

${ }^{1}$ M.Sc, Centre for Organic Farming (309), University of Hohenheim, Stuttgart, Germany

${ }^{2}$ Professor, Department of Agronomy, S. V. Agricultural College (ANGRAU), Tirupati, Chittoor, Andhra Pradesh, India

${ }^{3}$ Associate Dean, Department of Agronomy, Agricultural College, (ANGRAU),

Mahanandi, Kurnool, Andhra Pradesh, India

${ }^{4}$ Principal Scientist, Department of Soil Science and Agricultural Chemistry,

Regional Agricultural Research Station, Tirupati, Chittoor, Andhra Pradesh, India

*Corresponding Author: Prasanth B, M.Sc, Centre for Organic Farming (309),

University of Hohenheim, Germany.
Received: March 18, 2021

Published: April 23, 2021

(C) All rights are reserved by Prasanth B., et al.

\begin{abstract}
A field trial entitled "Evaluation of biofertilizers for phosphorus economy in sweet corn (Zea mays L.)" was executed during kharif, 2018 on sandy loam soils of S.V. Agricultural College, Tirupati campus of Acharya N.G. Ranga Agricultural University. The experiment was structured in a randomized block design with ten treatments and three replications. The different experimental treatments consists different phosphorus management practices. Phosphorus levels failed to exert significant influence on nitrogen and potassium content of sweet corn. The higher post-harvest soil available nitrogen and phosphorus status was noticed with $100 \%$ recommended

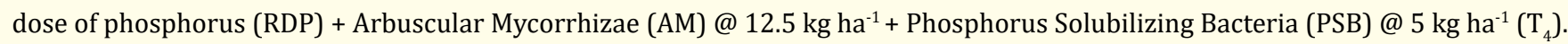
Higher post-harvest soil available potassium was registered with 100\% RDP + AM @ $12.5 \mathrm{~kg} \mathrm{ha}^{-1}\left(\mathrm{~T}_{2}\right)$. Application of 50\% RDP + PSB @ $5 \mathrm{~kg} \mathrm{ha}^{-1}\left(\mathrm{~T}_{8}\right)$ resulted in lower post - harvest soil nitrogen and phosphorus, in comparison with the remaining treatments tested. Higher partial factor productivity of phosphorus (Pfp) was recorded with 50\% RDP + AM @ 12.5 kg ha-1 + PSB @ 5 kg ha-1 ( $\mathrm{T}_{10}$ ). Considerably lower partial factor productivity of phosphorus was registered with $100 \% \mathrm{RDP}\left(\mathrm{T}_{1}\right)$.
\end{abstract}

Keywords: Phosphorus; Biofertilizers; Phosphorus Solubulizing Bacteria; Arbuscular Mycorrhizae

\section{Introduction}

Higher productive potential (22 $\mathrm{t} \mathrm{ha}^{-1}$ ) of maize (Zea mays L.) crop than any other remaining cereal validates its title as a miracle crop or Queen of cereals. When compared with other essential nutrients, nitrogen and phosphorus requirement is higher for maize crop for its better growth and yield. As an exhaustive cereal, to yield a single tonne of grain it approximately drains $24 \mathrm{~kg}$ of nitrogen, $6 \mathrm{~kg}$ phosphorus and $18 \mathrm{~kg}$ of potassium. Raising awareness on negative impacts of chemical based exploitative agriculture drew attention on organics application that includes biofertilizers. Biofertilizers are the economical and eco-friendly nutrient inputs capable of supplying macro, micro and secondary nutrients. Biofertilizers also found to save the chemical fertilizer application of the crops by 25-50 per cent without disrupting the soil productivity 
and fertility. Application of inorganic phosphorus with a mobiliser/ solubilizer could decrease the chemical phosphorus quantity supplied, through solubuliziation of insoluble phosphorus and reduction of chemical fixation.

\section{Materials and Methods}

The field trial was conducted in Field No. 102 of S. V. Agricultural College, Tirupati of Acharya N. G. Ranga Agricultural University. The field was geographically located at $13.5^{\circ} \mathrm{N}$ latitude and $79.5^{\circ} \mathrm{E}$ longitude in the Southern Agro Climatic Zone of Andhra Pradesh state.

Soil characteristics of the experimental site

The values and methods followed for soil analysis are presented below in table 1 . Review of the soil test reports revealed that the experimented soil was sandy clay loam with neutral in soil reaction. The experimental site found to be deficit in organic carbon and available nitrogen alongside with higher available soil phosphorus and intermediately available potassium.

\begin{tabular}{|c|c|c|c|}
\hline Particulars & Value & $\begin{array}{l}\text { Method of } \\
\text { analysis }\end{array}$ & References \\
\hline \multicolumn{4}{|c|}{ A. Physical properties } \\
\hline Sand (\%) & 64.9 & \multirow{4}{*}{$\begin{array}{l}\text { Bouyoucas } \\
\text { hydrometer }\end{array}$} & \multirow[t]{4}{*}{ Piper [1] } \\
\hline Silt (\%) & 11.0 & & \\
\hline Clay (\%) & 24.1 & & \\
\hline Textural class & $\begin{array}{c}\text { Sandy } \\
\text { clay loam }\end{array}$ & & \\
\hline \multicolumn{4}{|c|}{ B. Physico chemical characteristics } \\
\hline $\begin{array}{l}\text { Soil pH (1: } 2.5 \text { soil } \\
\text { water suspension) }\end{array}$ & 6.6 & $\begin{array}{l}\text { Glass elec- } \\
\text { trode } \mathrm{pH} \\
\text { meter }\end{array}$ & Piper [1] \\
\hline $\mathrm{EC}\left(\mathrm{dS} \mathrm{m} \mathrm{m}^{-1}\right)$ & 0.08 & $\begin{array}{l}\text { Conductivity } \\
\text { bridge }\end{array}$ & Jackson [2] \\
\hline Organic carbon $(\%)$ & 0.43 & \multirow{2}{*}{$\begin{array}{l}\text { Wet digestion } \\
\text { method }\end{array}$} & \multirow{2}{*}{$\begin{array}{c}\text { Walkely and } \\
\text { Black [3] }\end{array}$} \\
\hline Organic matter (\%) & 0.73 & & \\
\hline \multicolumn{4}{|c|}{ C. Chemical characteristics } \\
\hline $\begin{array}{l}\text { Available nitrogen } \\
\left(\mathrm{kg} \mathrm{ha}^{-1}\right)\end{array}$ & 206.3 & $\begin{array}{c}\text { Alkaline per- } \\
\text { manganate } \\
\text { method }\end{array}$ & $\begin{array}{l}\text { Subbiah and } \\
\text { Asija [4] }\end{array}$ \\
\hline $\begin{array}{l}\text { Available phospho- } \\
\text { rous }\left(\mathrm{kg} \mathrm{ha}^{-1}\right)\end{array}$ & 60.0 & $\begin{array}{l}\text { Olsen's } \\
\text { method }\end{array}$ & $\begin{array}{c}\text { Olsen., et al. } \\
{[5]}\end{array}$ \\
\hline $\begin{array}{l}\text { Available potas- } \\
\text { sium }\left(\mathrm{kg} \mathrm{ha}^{-1}\right)\end{array}$ & 258.0 & $\begin{array}{l}\text { Flame pho- } \\
\text { tometry }\end{array}$ & Jackson [2] \\
\hline
\end{tabular}

Table 1: Physico - Chemical properties of the experimental field.

\section{Experimental details}

The field experiment was conducted by using Randomized Block Design (RBD) with ten treatments and three replications. The details of the treatment tested are as follows:

- $\mathrm{T}_{1}: 100 \% \mathrm{RDP}$ (recommended dose of phosphorus)

- $\mathrm{T}_{2}: 100 \% \mathrm{RDP}+\mathrm{AM}$ (Arbuscular Mycorrhizae) @ $12.5 \mathrm{~kg} \mathrm{ha}^{-1}$

- $\mathrm{T}_{3}: 100 \%$ RDP + PSB (Phosphate solubilizing bacteria) @ 5 kg ha $^{-1}$

- $\mathrm{T}_{4}: 100 \% \mathrm{RDP}+\mathrm{PSB} @ 5 \mathrm{~kg} \mathrm{ha} \mathrm{k}^{-1}+\mathrm{AM} @ 12.5 \mathrm{~kg} \mathrm{ha}^{-1}$

- $\mathrm{T}_{5}: 75 \% \mathrm{RDP}+\mathrm{AM} @ 12.5 \mathrm{~kg} \mathrm{ha}^{-1}$

- $\quad \mathrm{T}_{6}: 75 \% \mathrm{RDP}+\mathrm{PSB} @ 5 \mathrm{~kg} \mathrm{ha}^{-1}$

- $\quad \mathrm{T}_{7}: 75 \% \mathrm{RDP}+\mathrm{PSB} @ 5 \mathrm{~kg} \mathrm{ha}^{-1}+\mathrm{AM} @ 12.5 \mathrm{~kg} \mathrm{ha}^{-1}$

- $\mathrm{T}_{8}: 50 \% \mathrm{RDP}+\mathrm{AM} @ 12.5 \mathrm{~kg} \mathrm{ha}^{-1}$

- $\mathrm{T}_{9}: 50 \% \mathrm{RDP}+\mathrm{PSB} @ 5 \mathrm{~kg} \mathrm{ha}^{-1}$

- $\mathrm{T}_{10}: 50 \% \mathrm{RDP}+\mathrm{PSB} @ 5 \mathrm{~kg} \mathrm{ha}^{-1}+\mathrm{AM} @ 12.5 \mathrm{~kg} \mathrm{ha}^{-1}$

Cultivation minutiae

Manures

Farm Yard Manure (FYM) was applied along with the biofertilizers as per the treatments and thoroughly incorporated into the soil at the time of sowing. A representative sample of FYM was also taken and analysed for available nitrogen, phosphorus and potash content. The contents are furnished below in table 2 .

\begin{tabular}{|l|c|c|}
\hline S. No. & Component & Content on dry weight basis (\%) \\
\hline 1. & Nitrogen $(\mathrm{N})$ & 0.51 \\
\hline 2. & Phosphorus $\left(\mathrm{P}_{2} \mathrm{O}_{5}\right)$ & 0.25 \\
\hline 3. & Potash $\left(\mathrm{K}_{2} \mathrm{O}\right)$ & 0.52 \\
\hline
\end{tabular}

Table 2: Nutrient content of FYM.

\section{Fertilisers}

Entire dose of phosphorous and potassium was applied basally as per the respective treatment allocations. Equal splits of nitrogen were carried out by band placement at three different growth stages of the crop namely basal, knee high and the tasseling stage. The nutrient recommendation for better growth of sweet corn crop was $180 \mathrm{~kg} \mathrm{~N}, 60 \mathrm{~kg} \mathrm{P}_{2} \mathrm{O}_{5}$ and $50 \mathrm{~kg} \mathrm{~K}_{2} \mathrm{O} \mathrm{ha}^{-1}$.

\section{Biofertilizer}

The two phosphorus biofertilizers i.e. PSB @ $5 \mathrm{~kg} \mathrm{ha}^{-1}$ and AM @ $12.5 \mathrm{~kg} \mathrm{ha}^{-1}$ were mixed with $500 \mathrm{~g}$ of well powdered dry FYM and

Citation: Prasanth B., et al. "Soil and Plant Nutrient Status as Influenced by Phosphorus Biofertilizers in Sweet Corn (Zea mays L.)". Acta Scientific Agriculture 5.5 (2021): 62-68. 
applied at the time of sowing in the furrows adjacent to crop rows.

\section{Phosphorus Balance}

Phosphorus balance for the system was worked out as

$\mathrm{x}=\mathrm{a}-(\mathrm{b}+\mathrm{c})$

Where,

$\mathrm{x}=$ Phosphorus $\left(\mathrm{kg} \mathrm{ha}^{-1}\right)$ loss or gain at the time of the crop harvest $a=$ Sum of initial status of the available phosphorus in soil and addition of phosphorus through inorganic source to the crop

$\mathrm{b}=$ Quantity of phosphorus $\left(\mathrm{kg} \mathrm{ha}^{-1}\right)$ removed by sweet corn crop

$\mathrm{c}=$ Actual balance of available phosphorus $\left(\mathrm{kg} \mathrm{ha}^{-1}\right)$ at the end of sweet corn harvest.

\section{Nutrient content}

For estimating nitrogen, phosphorus and potassium content in plants, well dried plant were used. Samples from each plot were oven dried, powdered and used for chemical analysis.

- Nitrogen content: Nitrogen content in dry matter was estimated by Subbiah and Asija [4] method.

- Phosphorus content: After Di-acid digestion, the plant samples were analysed by vanado-molybdo phosphoric acid method for their phosphorus content [2]. Phosphorus content in the plant sample represented through development of yellow colour which can be identified by using spectrophotometer.

- Potassium content: Potassium content of the extract of diacid digested material was determined by using flame photometer.

\section{Partial factor productivity (Pfp)}

The partial factor productivity (Pfp) is an integrative index to delineate the crop nutrient use efficiency by comparing the total grain yield to its nutrient utilization [6]. Partial factor productivity is computed as a ratio between crop economic yield and total amount of the nutrients applied. The standard units for partial factor productivity is $\mathrm{kg}_{\text {grain }} \mathrm{kg}^{-1}$ nutrient.

Partial factor productivity $=$

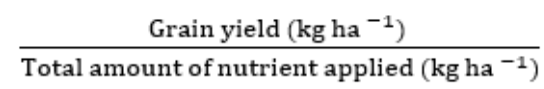

\section{Results and Discussion}

\section{Post-harvest soil fertility status}

Soil available nitrogen

The results of investigation showed that application of organic and inorganic phosphorus sources significantly influenced the available nitrogen status after harvest of the crop. The highest post-harvest soil available nitrogen was registered with $100 \%$ RDP + AM@ $12.5 \mathrm{~kg} \mathrm{ha}^{-1}+$ PSB @ $5 \mathrm{~kg} \mathrm{ha}^{-1}\left(\mathrm{~T}_{4}\right)$. The lowest soil available nitrogen was found with 50\% RDP + PSB @ $5 \mathrm{~kg} \mathrm{ha}^{-1}\left(\mathrm{~T}_{9}\right)$.

The increased availability of nitrogen from $\mathrm{T}_{4}(100 \% \mathrm{RDP}+\mathrm{AM}$ @ $12.5 \mathrm{~kg} \mathrm{ha}^{-1}+$ PSB @ $5 \mathrm{~kg} \mathrm{ha}^{-1}$ ) during the later part of the crop growth was attributed to positive influence of adequate $P$ nutrition on $\mathrm{N}$ availability. The decrease in post-harvest nutrient ( $\mathrm{N}, \mathrm{P}$ and $\mathrm{K}$ ) status of soil compared to initial soil nutrient status was might be due to crop removal and its transformation in the soil as reported by Tetarwal., et al. [7], Singh., et al. [8] and Sharma., et al. [9].

\section{Soil available phosphorus}

Highest phosphorus content in soil was recorded with the application of $100 \%$ RDP + AM @ $12.5 \mathrm{~kg} \mathrm{ha}^{-1}$ + PSB @ $5 \mathrm{~kg} \mathrm{ha}^{-1}\left(\mathrm{~T}_{4}\right)$, which was significantly superior over rest of the phosphorus management practices tried (Table 3 and figure 1). Increment in the soil available phosphorus might be due to the stimulated microbial activity in regard to soil inoculation of biofertilizers which made fixed soil phosphorus (inorganic P), available to plants. The increased level of soil available phosphorus (100\% RDP + AM @ $12.5 \mathrm{~kg} \mathrm{ha}^{-1}$ + PSB @ $5 \mathrm{~kg} \mathrm{ha}^{-1}$ ) suffices the phosphorus demands of crop and thus excess remained in soil. Similar results are also stated by Shilpashree., et al. [10].

Positive effect of biofertilizer might be due to its ability to increase the availability of phosphorus in soil which was reflected by $100 \%$ RDP + AM @ $12.5 \mathrm{~kg} \mathrm{ha}^{-1}$ + PSB @ $5 \mathrm{~kg} \mathrm{ha}^{-1}\left(\mathrm{~T}_{4}\right), 100 \% \mathrm{RDP}+$ PSB @ $5 \mathrm{~kg} \mathrm{ha}^{-1}\left(\mathrm{~T}_{3}\right)$ and 100\% RDP + AM @ $12.5 \mathrm{~kg} \mathrm{ha}^{-1}\left(\mathrm{~T}_{2}\right)$ treatments. The lowest post-harvest soil phosphorus was registered with 50\% RDP + AM @ $12.5 \mathrm{~kg} \mathrm{ha}^{-1}\left(\mathrm{~T}_{8}\right)$. This might be due to lesser supply of phosphorus.

\section{Soil available potassium}

Phosphorus levels did not influence significantly the potassium content in soil. The potassium content in the soil was comparable with each other. However, numerically higher soil available potas- 
sium content at harvest was observed with 100\% RDP + AM @ 12.5 $\mathrm{kg} \mathrm{ha}^{-1}\left(\mathrm{~T}_{2}\right)$. Supply of 50\% RDP + AM @ $12.5 \mathrm{~kg} \mathrm{ha}^{-1}+$ PSB @ $5 \mathrm{~kg}$ $\mathrm{ha}^{-1}\left(\mathrm{~T}_{10}\right)$ was resulted in the lowest soil available potassium.

\begin{tabular}{|c|c|c|c|}
\hline Treatments & $\begin{array}{l}\text { Available } \\
\text { Nitrogen }\end{array}$ & $\begin{array}{c}\text { Available } \\
\text { Phosphorus }\end{array}$ & $\begin{array}{l}\text { Available } \\
\text { Potassium }\end{array}$ \\
\hline $\begin{array}{l}\mathrm{T}_{1}-100 \% \text { recom- } \\
\text { mended dose of } \mathrm{P}_{2} \mathrm{O}_{5} \\
(\mathrm{RDP})\end{array}$ & 171.3 & 64.1 & 233.4 \\
\hline $\begin{array}{l}\mathrm{T}_{2}-100 \% \mathrm{RDP}+\mathrm{AM} \\
@ 12.5 \mathrm{~kg} \mathrm{ha}^{-1}\end{array}$ & 177.0 & 66.0 & 238.3 \\
\hline $\begin{array}{l}\mathrm{T}_{3}-100 \% \mathrm{RDP}+\mathrm{PSB} \\
\text { @ } 5 \mathrm{~kg} \mathrm{ha}^{-1}\end{array}$ & 178.4 & 66.3 & 232.2 \\
\hline $\begin{array}{l}\mathrm{T}_{4}-100 \% \mathrm{RDP}+\mathrm{AM} \\
@ 12.5 \mathrm{~kg} \mathrm{ha}^{-1}+\mathrm{PSB} \\
@ 5 \mathrm{~kg} \mathrm{ha}^{-1}\end{array}$ & 187.1 & 72.3 & 230.0 \\
\hline $\begin{array}{l}\mathrm{T}_{5}-75 \% \mathrm{RDP}+\mathrm{AM} @ \\
12.5 \mathrm{~kg} \mathrm{ha}^{-1}\end{array}$ & 163.4 & 57.2 & 215.6 \\
\hline $\begin{array}{l}\mathrm{T}_{6}-75 \% \mathrm{RDP}+\mathrm{PSB} @ \\
5 \mathrm{~kg} \mathrm{ha}^{-1}\end{array}$ & 168.0 & 60.0 & 216.4 \\
\hline $\begin{array}{l}\mathrm{T}_{7}-75 \% \mathrm{RDP}+\mathrm{AM} @ \\
12.5 \mathrm{~kg} \mathrm{ha}{ }^{-1}+\mathrm{PSB} @ 5 \\
\mathrm{~kg} \mathrm{ha}^{-1}\end{array}$ & 172.3 & 64.3 & 225.7 \\
\hline $\begin{array}{l}\mathrm{T}_{8}-50 \% \mathrm{RDP}+\mathrm{AM} @ \\
12.5 \mathrm{~kg} \mathrm{ha}^{-1}\end{array}$ & 160.9 & 48.6 & 213.3 \\
\hline $\begin{array}{l}\mathrm{T}_{9}-50 \% \mathrm{RDP}+\mathrm{PSB} @ \\
5 \mathrm{~kg} \mathrm{ha}^{-1}\end{array}$ & 160.0 & 50.0 & 212.3 \\
\hline $\begin{array}{l}\mathrm{T}_{10}-50 \% \mathrm{RDP}+\mathrm{AM} @ \\
12.5 \mathrm{~kg} \mathrm{ha}^{-1}+\mathrm{PSB} @ 5 \\
\mathrm{~kg} \mathrm{ha}^{-1}\end{array}$ & 161.3 & 50.6 & 210.4 \\
\hline SEm \pm & 5.68 & 1.87 & 6.79 \\
\hline $\mathrm{CD}(\mathrm{P}=0.05)$ & 16.8 & 5.5 & NS \\
\hline Mean & 169.9 & 59.9 & 222.7 \\
\hline
\end{tabular}

Table 3: Post - harvest soil available nutrient status $\left(\mathrm{kg} \mathrm{ha}^{-1}\right)$ as affected by various phosphorus levels.

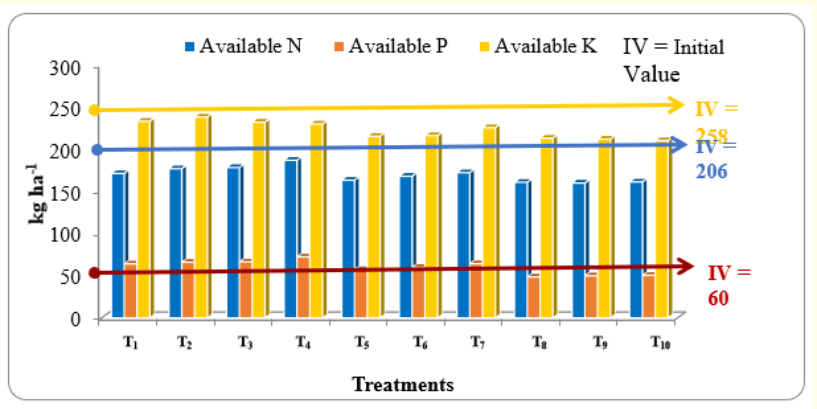

Figure 1: Post-harvest soil available nitrogen $(\mathrm{N})$, phosphorus (P205) and potassium (K20) (kg ha-1) as influenced by different phosphorus management practices.
Nutrient (NPK) content at harvest

Phosphorus levels failed to exert significant influence on nitrogen and potassium content of the sweet corn. However, numerically higher plant nitrogen content was observed with 50\% RDP + AM @ $12.5 \mathrm{~kg} \mathrm{ha}^{-1}\left(\mathrm{~T}_{8}\right)$. While, supply of $50 \% \mathrm{RDP}+\mathrm{AM} @ 12.5 \mathrm{~kg} \mathrm{ha}^{-1}$ + PSB @ $5 \mathrm{~kg} \mathrm{ha}^{-1}\left(\mathrm{~T}_{10}\right)$ resulted in higher potassium content (Table 4 and figure 2). Lowest values in terms of nitrogen and potassium content were with application of 100\% RDP + AM @ $12.5 \mathrm{~kg} \mathrm{ha}^{-1}+$ PSB @ $5 \mathrm{~kg} \mathrm{ha}^{-1}\left(\mathrm{~T}_{4}\right)$.

Higher phosphorus content of sweet corn was recorded with $100 \%$ RDP + PSB @ $5 \mathrm{~kg} \mathrm{ha}^{-1}$ + AM @ $12.5 \mathrm{~kg} \mathrm{ha}^{-1}\left(\mathrm{~T}_{4}\right)$ and the next best treatment was $100 \%$ RDP alone $\left(\mathrm{T}_{1}\right)$. Phosphorus uptake was registered lower with application of 50\% RDP + AM @ $12.5 \mathrm{~kg} \mathrm{ha}^{-1}$ $\left(\mathrm{T}_{8}\right)$.

The favourable effect of phosphorus fertilization on nutrient content might be owing to better nutritional environment in soils and positive and significant effect in root formation, proliferation and their functional activities [11]. These results are in conformity with the findings of Siva Jyothi et al. [12] who reported that application of $50 \%$ recommended dose of phosphorus recorded higher uptake of nutrients in phosphorus rich vertisols.

\begin{tabular}{|c|c|c|c|}
\hline Treatments & $\begin{array}{l}\text { Nitro- } \\
\text { gen }\end{array}$ & $\begin{array}{l}\text { Phos- } \\
\text { phorus }\end{array}$ & $\begin{array}{l}\text { Potas- } \\
\text { sium }\end{array}$ \\
\hline $\begin{array}{l}\mathrm{T}_{1}-100 \% \text { recommended dose of } \\
\mathrm{P}_{2} \mathrm{O}_{5}(\mathrm{RDP})\end{array}$ & 1.30 & 0.34 & 1.33 \\
\hline $\mathrm{T}_{2}-100 \% \mathrm{RDP}+\mathrm{AM} @ 12.5 \mathrm{~kg} \mathrm{ha}^{-1}$ & 1.30 & 0.33 & 1.30 \\
\hline $\mathrm{T}_{3}-100 \% \mathrm{RDP}+\mathrm{PSB} @ 5 \mathrm{~kg} \mathrm{ha}^{-1}$ & 1.30 & 0.33 & 1.29 \\
\hline $\begin{array}{l}\mathrm{T}_{4}-100 \% \mathrm{RDP}+\mathrm{AM} @ 12.5 \mathrm{~kg} \mathrm{ha}^{-1} \\
+ \text { PSB @ } 5 \mathrm{~kg} \mathrm{ha}^{-1}\end{array}$ & 1.27 & 0.38 & 1.26 \\
\hline $\mathrm{T}_{5}-75 \% \mathrm{RDP}+\mathrm{AM} @ 12.5 \mathrm{~kg} \mathrm{ha}^{-1}$ & 1.32 & 0.31 & 1.29 \\
\hline $\mathrm{T}_{6}-75 \%$ RDP + PSB @ $5 \mathrm{~kg} \mathrm{ha}^{-1}$ & 1.31 & 0.32 & 1.31 \\
\hline $\begin{array}{l}\mathrm{T}_{7}-75 \% \mathrm{RDP}+\mathrm{AM} @ 12.5 \mathrm{~kg} \mathrm{ha}^{-1}+ \\
\mathrm{PSB} @ 5 \mathrm{~kg} \mathrm{ha}^{-1}\end{array}$ & 1.31 & 0.33 & 1.29 \\
\hline $\mathrm{T}_{8}-50 \% \mathrm{RDP}+\mathrm{AM} @ 12.5 \mathrm{~kg} \mathrm{ha}^{-1}$ & 1.37 & 0.26 & 1.35 \\
\hline $\mathrm{T}_{9}-50 \%$ RDP + PSB @ $5 \mathrm{~kg} \mathrm{ha}^{-1}$ & 1.36 & 0.27 & 1.35 \\
\hline $\begin{array}{l}\mathrm{T}_{10}-50 \% \mathrm{RDP}+\mathrm{AM} @ 12.5 \mathrm{~kg} \mathrm{ha}^{-1} \\
+\mathrm{PSB} @ 5 \mathrm{~kg} \mathrm{ha}^{-1}\end{array}$ & 1.36 & 0.29 & 1.39 \\
\hline SEm \pm & 0.05 & 0.02 & 0.06 \\
\hline $\mathrm{CD}(\mathrm{P}=0.05)$ & NS & 0.05 & NS \\
\hline Mean & 1.32 & 0.32 & 1.32 \\
\hline
\end{tabular}

Table 4: NPK content (\%) of sweet corn at harvest as affected by various phosphorus levels. 


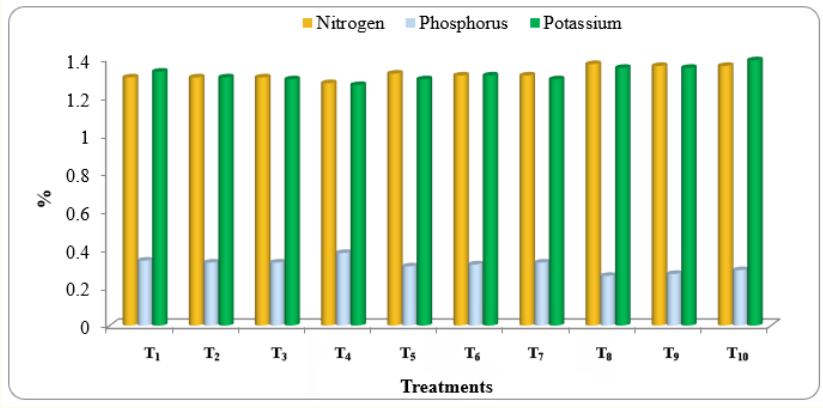

Figure 2: NPK content (\%) of sweet corn at harvest as affected by various phosphorus levels.

\section{Partial factor productivity (Pfp)}

The maximum partial factor productivity of phosphorus was recorded with 50\% RDP + AM @ $12.5 \mathrm{~kg} \mathrm{ha}^{-1}+\mathrm{PSB} @ 5 \mathrm{~kg} \mathrm{ha}^{-1}\left(\mathrm{~T}_{10}\right)$, which was closely followed by $50 \%$ RDP + PSB @ $5 \mathrm{~kg} \mathrm{ha}^{-1}\left(\mathrm{~T}_{9}\right)$ and $50 \%$ RDP + AM @ $12.5 \mathrm{~kg} \mathrm{ha}^{-1}\left(\mathrm{~T}_{8}\right)$ which maintained parity among them (Table 5 and figure 3 ).

Application of $100 \%$ RDP $\left(\mathrm{T}_{1}\right)$ resulted in significantly lower partial factor productivity of phosphorus. The probable reason might be due to the fact that application of inorganics alone might have resulted in phosphorus fixation and thereby reduced the phosphorus uptake and yield. Phosphorus use efficiency was found to be better with lower doses of phosphorus.

\begin{tabular}{|c|c|}
\hline Treatments & $\begin{array}{l}\text { Partial factor } \\
\text { productivity for } P\end{array}$ \\
\hline $\begin{array}{l}\mathrm{T}_{1}-100 \% \text { recommended dose of } \mathrm{P}_{2} \mathrm{O}_{5} \\
\text { (RDP) }\end{array}$ & 218.3 \\
\hline $\mathrm{T}_{2}-100 \% \mathrm{RDP}+\mathrm{AM} @ 12.5 \mathrm{~kg} \mathrm{ha}^{-1}$ & 224.5 \\
\hline $\mathrm{T}_{3}-100 \%$ RDP + PSB @ $5 \mathrm{~kg} \mathrm{ha}^{-1}$ & 227.2 \\
\hline $\begin{array}{l}\mathrm{T}_{4}-100 \% \mathrm{RDP}+\mathrm{AM} @ 12.5 \mathrm{~kg} \mathrm{ha}^{-1}+\mathrm{PSB} \\
@ 5 \mathrm{~kg} \mathrm{ha}^{-1}\end{array}$ & 232.2 \\
\hline $\mathrm{T}_{5}-75 \% \mathrm{RDP}+\mathrm{AM} @ 12.5 \mathrm{~kg} \mathrm{ha}^{-1}$ & 288.1 \\
\hline $\mathrm{T}_{6}-75 \%$ RDP + PSB @ $5 \mathrm{~kg} \mathrm{ha}^{-1}$ & 290.6 \\
\hline $\begin{array}{l}\mathrm{T}_{7}-75 \% \mathrm{RDP}+\mathrm{AM} @ 12.5 \mathrm{~kg} \mathrm{ha}^{-1}+\mathrm{PSB} @ \\
5 \mathrm{~kg} \mathrm{ha}^{-1}\end{array}$ & 297.3 \\
\hline $\mathrm{T}_{8}-50 \% \mathrm{RDP}+\mathrm{AM} @ 12.5 \mathrm{~kg} \mathrm{ha}^{-1}$ & 400.1 \\
\hline $\mathrm{T}_{9}-50 \%$ RDP + PSB @ $5 \mathrm{~kg} \mathrm{ha}^{-1}$ & 403.6 \\
\hline $\begin{array}{l}\mathrm{T}_{10}-50 \% \mathrm{RDP}+\mathrm{AM} @ 12.5 \mathrm{~kg} \mathrm{ha}^{-1}+\mathrm{PSB} \\
@ 5 \mathrm{~kg} \mathrm{ha}^{-1}\end{array}$ & 406.1 \\
\hline SEm \pm & 10.21 \\
\hline $\mathrm{CD}(\mathrm{P}=0.05)$ & 30.3 \\
\hline
\end{tabular}

Table 5: Partial factor productivity $\left(\mathrm{kg}_{\text {grain }} \mathrm{kg}^{-1} \mathrm{P}\right)$ of sweet corn as affected by various phosphorus levels.

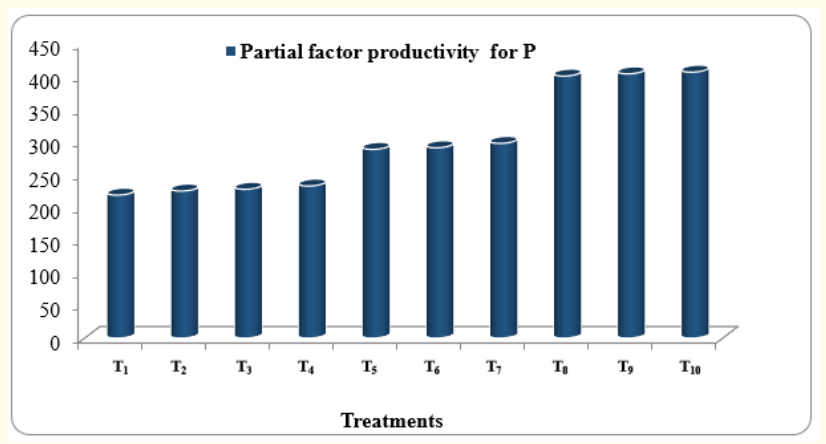

Figure 3: Partial factor productivity $\left(\mathrm{kg}_{\text {grain }} \mathrm{kg}^{-1} \mathrm{P}\right)$ of sweet corn as affected by various phosphorus levels.

\section{Phosphorus balance}

The balance sheet of post harvest available soil $P$ as influenced by different phosphorus management practices was worked out and presented in table 6 .

Initially the soil had $25.8 \mathrm{~kg}$ available $\mathrm{P}$ ha $^{-1}$. The sweet corn crop extracted increasingly higher quantity of phosphorus from the soil with increased application rate. Maximum gain $(30.10 \mathrm{~kg}$ $\mathrm{P} \mathrm{ha}^{-1}$ ) was observed with application of $100 \%$ RDP + AM @ 12.5 $\mathrm{kg} \mathrm{ha}^{-1}+\mathrm{PSB} @ 5 \mathrm{~kg} \mathrm{ha}^{-1}\left(\mathrm{~T}_{4}\right)$, whereas the minimum gain $(+2.00$ kg P ha-1) was with 50\% RDP + AM @ $12.5 \mathrm{~kg} \mathrm{ha}^{-1}\left(\mathrm{~T}_{8}\right)$. This could be due to increased phosphorus supply from both inorganics and biofertilizers, which converts the unavailable P into available form.

\section{Conclusion}

The present investigation revealed that application of $100 \%$ RDP with AM @ $12.5 \mathrm{~kg} \mathrm{ha}^{-1}$ and PSB @ $5 \mathrm{~kg} \mathrm{ha}^{-1}$ is the most profitable integrated phosphorus management practice in sweet corn. The experimental findings have clearly indicated that in sweet corn biofertilizers like AM and PSB along with chemical fertilizers could be effectively used in combination to benefit the crop and improve soil health. While among the reduced doses of application, $75 \%$ RDP + PSB @ 5 kg ha-1 + AM @ $12.5 \mathrm{~kg} \mathrm{ha}^{-1}$ was proven to be ecologically safe practice by preserving the favourable soil balance, compared to $100 \%$ RDP. Hence, combined use of biofertilizers with inorganic chemicals could suit or even outpace the sole chemical nutrient-based strategy in a long run. 


\begin{tabular}{|c|c|c|c|c|c|c|c|}
\hline Treatments & $\begin{array}{l}\text { Initial } \\
\text { Soil P }\end{array}$ & $\begin{array}{c}\text { Fertilizer } \\
\text { applied }\end{array}$ & $\begin{array}{c}\text { Total initial } \\
\text { soil P + } \\
\text { Fertilizer P } \\
\text { applied }\end{array}$ & $\begin{array}{c}\text { Uptake } \\
\text { by the } \\
\text { crop }\end{array}$ & $\begin{array}{l}\text { Estimated } P \\
\text { at the end of } \\
\text { crop }\end{array}$ & $\begin{array}{l}\text { Actual bal- } \\
\text { ance of soil } \\
\text { available } P \\
\text { at harvest }\end{array}$ & $\begin{array}{l}\text { Net loss/ } \\
\text { gain }\end{array}$ \\
\hline & 1 & 2 & $3(1+2)$ & 4 & $5(3-4)$ & 6 & $7(6-5)$ \\
\hline $\mathrm{T}_{1}-100 \% \mathrm{RDP}$ & 60.00 & 60.00 & 85.80 & 36.70 & 49.10 & 64.10 & +15.00 \\
\hline $\mathrm{T}_{2}-100 \% \mathrm{RDP}+\mathrm{AM}$ & 60.00 & 60.00 & 85.80 & 36.90 & 48.90 & 66.00 & +17.10 \\
\hline $\mathrm{T}_{3}-100 \% \mathrm{RDP}+\mathrm{PSB}$ & 60.00 & 60.00 & 85.80 & 37.00 & 48.80 & 66.30 & +17.50 \\
\hline $\mathrm{T}_{4}-100 \% \mathrm{RDP}+\mathrm{AM}+\mathrm{PSB}$ & 60.00 & 60.00 & 85.80 & 43.60 & 42.20 & 72.30 & +30.10 \\
\hline $\mathrm{T}_{5}-75 \% \mathrm{RDP}+\mathrm{AM}$ & 60.00 & 45.00 & 79.35 & 32.50 & 46.85 & 57.20 & +10.35 \\
\hline $\mathrm{T}_{6}-75 \% \mathrm{RDP}+\mathrm{PSB}$ & 60.00 & 45.00 & 79.35 & 34.60 & 44.75 & 60.00 & +15.25 \\
\hline $\mathrm{T}_{7}-75 \% \mathrm{RDP}+\mathrm{AM}+\mathrm{PSB}$ & 60.00 & 45.00 & 79.35 & 36.20 & 43.15 & 64.30 & +21.15 \\
\hline $\mathrm{T}_{8}-50 \% \mathrm{RDP}+\mathrm{AM}$ & 60.00 & 30.00 & 72.90 & 26.30 & 46.60 & 48.60 & +2.00 \\
\hline $\mathrm{T}_{9}-50 \% \mathrm{RDP}+\mathrm{PSB}$ & 60.00 & 30.00 & 72.90 & 27.30 & 45.60 & 50.00 & +4.40 \\
\hline $\mathrm{T}_{10}-50 \% \mathrm{RDP}+\mathrm{AM}+\mathrm{PSB}$ & 60.00 & 30.00 & 72.90 & 30.00 & 42.90 & 50.60 & +7.70 \\
\hline
\end{tabular}

Table 6: Balance sheet of available phosphorus $\left(\mathrm{kg} \mathrm{ha}^{-1}\right)$ at the end of the sweet corn crop.

*Fertilizer applied in column 2 was converted to $\mathrm{P}\left(\mathrm{P}_{2} \mathrm{O}_{5} \mathrm{X} 0.43=\mathrm{P}\right)$

\section{Bibliography}

1. Piper CS. "Soil and Plant Analysis". Inter Science Publishers, New York (1966): 47-49.

2. Jackson MC. "Soil Chemical Analysis. Prentice Hall of India". Private limited, New Delhi, 498 (1973).

3. Walkley A and Black CA. "An estimation of digestion method for determining soil organic matter and proposed modification of chromic acid titration method". Soil Science 37.1 (1934): 29-34.

4. Subbiah BV and Asija GL. "Rapid procedure for estimation of available nitrogen in soils". Current Science 25 (1956): 259260.

5. Olsen SR., et al. "Estimation of available phosphorus in soil by extraction with sodium bicarbonate". United States Department of Agriculture (1954): 939.

6. Cassman K., et al. "Soil organic matter and the indigenous nitrogen supply of intensive irrigated rice systems in the tropics". Plant and Soil 10 (1996): 2537-2552.
7. Tetarwal JP., et al. "Effect of integrated nutrient management on productivity, profitability, nutrient uptake and soil fertility in rainfed maize (Zea mays)". Indian Journal of Agronomy 56.4 (2011): 373-376.

8. Singh G., et al. "Effect of enriched FYM with fertilizers and biofertilizers on yield, harvest index, protein, nitrogen and phosphorus content in grains". Journal of Progressive Agriculture 2.3 (2011): 65-67.

9. Sharma SK., et al. "Effect of balanced fertilization on productivity and soil fertility status of maize". Research on Crops 13.1 (2012): 95-99.

10. Shilpashree VM., et al. "Influence of integrated nutrient management practices on productivity of maize crop". Indian Journal of Fundamental and Applied Sciences 2.1 (2012): 45-50.

11. Kampawat BS and Rathore SS. "Response of maize (Zea mays)wheat (Triticum aestivum) cropping systems". Indian Journal of Agronomy 40 (1995): 26-29. 
12. Siva Jyothi V., et al. "Influence of levels of phosphorus, farm yard manure and green manure on rice yield and economics in a phosphorus rich vertisol". The Andhra Agricultural Journal 60.4 (2013): 828-831.

\section{Assets from publication with us}

- Prompt Acknowledgement after receiving the article

- Thorough Double blinded peer review

- Rapid Publication

- Issue of Publication Certificate

- High visibility of your Published work

Website: www.actascientific.com/

Submit Article: www.actascientific.com/submission.php

Email us: editor@actascientific.com

Contact us: +919182824667 